\title{
Implementation of a ventilator care bundle to reduce the incidence of ventilator acquired pneumonia
}

\author{
AK Mandal ${ }^{1}$, A Sharma ${ }^{2 *}$ \\ From International Conference on Prevention \& Infection Control (ICPIC 2011) \\ Geneva, Switzerland. 29 June - 2 July 2011
}

\section{Introduction / objectives}

Ventilator acquired pneumonia (VAP) is a nosocomial infection that occurs in patients receiving mechanical ventilation for at least $48 \mathrm{hrs}$. We observed a high rate of VAP of 18.3 per 1000 ventilator days in 2008 and 8.6 per thousand ventilatordays in 2009 in one of our intensive care units at Fortis Hsopital.Reduction of VAP through the implemetation of Ventilator care bundles was taken as one of the quality improvement initiative for the unit.

\section{Methods}

The study was divided into preintervention, intervention and postintervention phases. Data was collected on the VAP rates, hand hygiene and ventilator care bundle practices of the team during preintervention and postintervention phase through knowledge surveys and observational surveys of the team. A workshop on care bundles supported by introduction of an insertion and maintainence tool for Ventilators and oral care were the interventions adopted.

\section{Results}

The surveillance of ventilator bundle showed an improvement of $64 \%$ in the postintervention phase as compared to zero percent in the pre-intervention phaase. The VAP rates in 2010 after the introduction of the bundle towards the end of 2009 were observed to be significantly lower than those in 2008 and 2009. The average (mean) VAP rates over 12 months dropped from 8.6 per 1000 ventilator days in 2009 to 2.1 per 1000 ventilator days in 2010 over a span of one year.

${ }^{2}$ Infection control, Fortis Hospital, Mohali, India

Full list of author information is available at the end of the article

\section{Conclusion}

Implementation of ventilator care bundle resulted in decrease in VAP in the unit over a period of one year in 2010. A lot of other supporting activities like oral care, cleaning and disinfection of ventilator parts were improved uponi simultaneously and it would have also played a role in the reduced VAP rates.

\section{Disclosure of interest}

None declared.

\section{Author details}

${ }^{1}$ Pulmonary Medicine, Fortis Hospital, Mohali, India. ${ }^{2}$ Infection control, Fortis Hospital, Mohali, India.

Published: 29 June 2011

doi:10.1186/1753-6561-5-S6-P71

Cite this article as: Mandal and Sharma: Implementation of a ventilator care bundle to reduce the incidence of ventilator acquired pneumonia. BMC Proceedings 2011 5(Suppl 6):P71.

Submit your next manuscript to BioMed Central and take full advantage of:

- Convenient online submission

- Thorough peer review

- No space constraints or color figure charges

- Immediate publication on acceptance

- Inclusion in PubMed, CAS, Scopus and Google Scholar

- Research which is freely available for redistribution 